\title{
A Drosophila melanogaster mitotype may have an adaptive meaning
}

\author{
D.V. Petrovskii ${ }^{1,2} \otimes$, L.P. Zakharenko ${ }^{1,3} \otimes$ \\ ${ }^{1}$ Institute of Cytology and Genetics, SB RAS, Novosibirsk, Russia \\ 2 Institute of Systematics and Ecology of Animals, SB RAS, Novosibirsk, Russia \\ ${ }^{3}$ Novosibirsk State University, Novosibirsk, Russia \\ 凶e-mail:dm_petr@ngs.ru; zakharlp@bionet.nsc.ru
}

\begin{abstract}
Several different mitochondrial clades have been found in natural populations of Drosophila melanogaster. Most often, the difference is in single nucleotide substitutions, some of which are conservative. Some clades are rare, and others dominate. It has been reported that clade III dominates over clades V and VI in seven populations of $D$. melanogaster. We compared $D$. melanogaster strains with different mitotypes by locomotor activity (using TriKinetics Drosophila Activity Monitor), energy expenditure (by indirect calorimetry, based on measuring oxygen consumption) and life span (under extreme conditions at $29^{\circ} \mathrm{C}$ ). The nuclear genomes of these strains were aligned for several generations by backcrosses. According to our data, individuals with the mitotype from clade III had a higher level of locomotor activity and longer life span. In terms of energy expenditure, the strains studied did not differ. However, the same level of energy expenditure may be differently distributed between the state of activity and the state of rest or sleep. If the energy expenditure during the sleep in flies with different locomotor activity is the same, then an individual with the same overall energy expenditure can move a greater distance or be active longer. This can be interpreted as an advantage of the strain with the mitotype from clade III compared to the other two mitotypes studied. If individuals have different energy expenditure values at rest, the strains with lower energy expenditure at rest spend less energy during forced inactivity. In this case, the mitotype from clade III should also be advantageous. What nucleotide substitutions in the mitotype from clade III can provide an adaptive advantage is not clear yet. We assume that individuals with widespread clade M(III) may have adaptive advantages compared to other mitotypes due to their greater locomotor activity even with the same energy expenditure. Further studies are required, for mitotypes are polymorphic for single nucleotide polymorphism not only between but also within the clades. Key words: Drosophila melanogaster; mitotype; life span; locomotor activity; energy expenditure.
\end{abstract}

For citation: Petrovskii D.V., Zakharenko L.P. A Drosophila melanogaster mitotype may have an adaptive meaning. Vavilovskii Zhurnal Genetiki i Selektsii = Vavilov Journal of Genetics and Breeding. 2019;23(3):370-374. DOI $10.18699 /$ VJ19.504

\section{Митотип Drosophila melanogaster может иметь адаптивное значение}

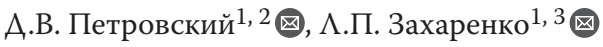 \\ 1 Федеральный исследовательский центр Институт цитологии и генетики Сибирского отделения Российской академии наук, Новосибирск, Россия \\ ${ }^{2}$ Институт систематики и экологии животных Сибирского отделения Российской академии наук, Новосибирск, Россия \\ ${ }^{3}$ Новосибирский национальный исследовательский государственный университет, Новосибирск, Россия \\ 凶e-mail:dm_petr@ngs.ru; zakharlp@bionet.nsc.ru
}

В природных популяциях Drosophila melanogaster обнаруживают несколько митохондриальных клад, отличающихся друг от друга по первичной последовательности. Чаще всего это однонуклеотидные замены, часть из них консервативна. Одни клады встречаются редко, другие доминируют. В семи исследованных на сегодняшний день популяциях D. melanogaster клада III преобладает по сравнению с кладами V и VI. Мы сравнивали линии D. melanogaster с разными митотипами, но с выровненными в течение нескольких поколений беккроссами ядерными геномами, по двигательной активности (с использованием Trikinetics Drosophila Activity Monitor), энергообмену (методом непрямой калориметрии, на основе измерения потребления кислорода) и по длительности жизни (в экстремальных условиях содержания при $29^{\circ} \mathrm{C}$ ). По нашим данным, у особей с митотипом, относящимся к кладе III, выше уровень локомоторной активности и больше продолжительность жизни. По энергопотреблению исследованные линии не различаются. Однако один и тот же уровень энергообмена может быть по-разному распределен между состоянием активности и состоянием покоя. Если энергообмен в состоянии покоя у мух с разной локомоторной активностью одинаков, то особь при одинаковых тратах суммарной энергии может перемещаться на большее расстояние или дольше проявлять активность. Это можно интерпретировать как преимущество линии 


\begin{abstract}
с митотипом, относящимся к кладе III, по сравнению с двумя другими исследованными митотипами, относящимися к кладам V и VI. Если особи имеют разный энергообмен в покое, то линии с наименьшим энергообменом в покое потратят меньше энергии при вынужденном бездействии. И в этом случае митотип, относящийся к кладе III, будет иметь преимущества. Какие нуклеотидные замены в этом митотипе могут обеспечивать адаптивное преимущество, пока остается непонятным. Мы предполагаем, что особи из широко распространенной клады III могут иметь адаптивные преимущества по сравнению с другими митотипами благодаря большей локомоторной активности даже при одинаковом энергообмене. Требуются дальнейшие исследования, поскольку митотипы полиморфны по набору однонуклеотидных замен не только между кладами, но и внутри клады.

Ключевые слова: Drosophila melanogaster; митотип; продолжительность жизни; локомоторная активность; энергообмен.
\end{abstract}

\section{Introduction}

The mitochondrial genome is responsible for supplying cell with energy. In particular, it encodes a number of the proteins involved in the Krebs cycle, $\beta$-oxidation of fatty acids, and oxidative phosphorylation. Many studies indicate that there is a link between the mtDNA structure and life span (Lehmann et al., 2008; Muradian et al., 2010). For example, it is thought that the mutation frequency in mtDNA of placental mammals enables lower production of reactive oxygen species (ROS) (Rottenberg, 2007). Different mito-haplotypes of Drosophila simulans vary in ATPase activity, mitochondrial cytochrome C content, hydrogen peroxide content, and other bioenergetic parameters (Katewa, Ballard, 2007). Though the mentioned authors used $D$. simulans from sympatric populations, the effect of mitonuclear interactions on the observed differences can hardly be ruled out (Stuart, Brown, 2006). Among numerous ageing theories, the free-radical theory of ageing takes a special place. According to this theory some ROS, specifically those produced in mitochondria, impair the cells (Harman 1956; Halliwell, 2012).

Due to the significant mtDNA variability, the difference between the mitochondria that belong to different strains may exceed one hundred SNPs (Zhu et al., 2014). The researchers studying mtDNA polymorphism in D. melanogaster identify several mitochondrial clades. One classification divides them into the $\mathrm{M}$ and $\mathrm{S}$ clades different by one conservative singlenucleotide substitution 37C/T (position 2187 in the sequence with GenBank accession number NC001709) (Richardson et al., 2012; Ilinsky, 2013; Ilinsky et al., 2013). Another classification defines eight clades grouping into M(I-V, VIII) and S(VI-VII). The clades are different by their SNP sets, which are partly conservative (Richardson et al., 2012; Early, Clark, 2013; Ilinsky, 2013). Clade M(III) prevails in such natural populations as Raleigh, North Carolina (United States) (Richardson et al., 2012), Beijing (China), Ithaca (NY, United States), Netherlands, Tasmania, and Zimbabwe (Early, Clark, 2013) if compared to clades $\mathrm{M}(\mathrm{V})$ and $\mathrm{S}(\mathrm{VI})$, and it is highly polymorphic with regard to its SNP set. According to (Maklakov et al., 2006), the intrapopulation variability may affect life span and other physiological parameters.

In the present study we compare strains with different mitotypes, such as a mito-haplotype from clade III (M(III)), a mito-haplotype from clade $\mathrm{V}$, and a mito-haplotype from clade IV (S(VI)), by their locomotor activity, energy expenditure, and life span to understand whether any of these strains have physiological advantages over others.

\section{Materials and methods}

Drosophila strains. Mitochondria are considered to be an important factor affecting life span and other physiological parameters. However, the variability of a mitochondrial genome is influenced by the genetic background determined by the nuclear genome (Clancy, 2008). While the mitochondrial genome is inherited from the mother, the nuclear genome is contributed by both parents. By means of backcrosses, this feature allows scientists to obtain strains with different mitotypes but the same nuclear DNA. Saturation backcrosses during at least 10 generations for male flies (strain Bi90) produced Drosophila strains having similar nuclear genomes and three different mitochondrial genomes: $\mathrm{M}(\mathrm{III}), \mathrm{M}(\mathrm{V})$, and $\mathrm{S}(\mathrm{VI})$. The Drosophila strains used in this study were provided by N.E. Gruntenko. Two generations of flies were treated with tetracycline $(0.25 \mathrm{mg} / \mathrm{ml})$ to make a Wolbachia-free strain and prevent the possible effect the bacteria may have on important physiological parameters (Gruntenko et al., 2017). It should be noted that this antibiotic does not affect Drosophila's life span (Min, Benzer, 1997). The strains were partly duplicated to avoid the possible effect of incomplete genome substitution (Gruntenko et al., 2017). The following strains based on the strain Bi90 nuclear genome were studied: M(III) - a mitotype from clade III (initial genome of strain W304, two lineages), $\mathrm{M}(\mathrm{V})$ - a mitotype from clade V (initial genome of strain B90, two lineages), and S(VI) - a mitotype from clade VI (initial genomes of strains W1118 (two lineages), W153 and W181 (one lineage each)).

The energy expenditure of the tested flies was studied by indirect calorimetry, measuring oxygen consumption in a hermetically sealed chamber with alkali. When breathing, animals consume oxygen and exhale carbon dioxide and water. The exhaled $\mathrm{CO}_{2}$ reacts with the alkali $(\mathrm{KOH})$ to form a solid matter $\left(\mathrm{K}_{2} \mathrm{CO}_{3}\right)$ so the initial pressure in the chamber falls proportionally to the amount of the consumed oxygen. The apparatus to carry out energy expenditure measurements was designed to be similar (with slight modifications) to that described in (Diarra et al., 1999). It consisted of ten thermostatic chambers (eight measuring chambers and two reference ones) of 3 cubic $\mathrm{ml}$ each and a single pressure sensor. Ten male flies (3-7 days old) were placed into each chamber. The experiment lasted from 11 a.m. to 4 p.m., the measurements starting one hour after acclimation of the flies to a temperature of $29^{\circ} \mathrm{C}$. The pressure drop in each chamber was measured twice, 6 min each time.

To estimate the energy expenditure, the inclination angle of the approximation curve on the pressure measurement 


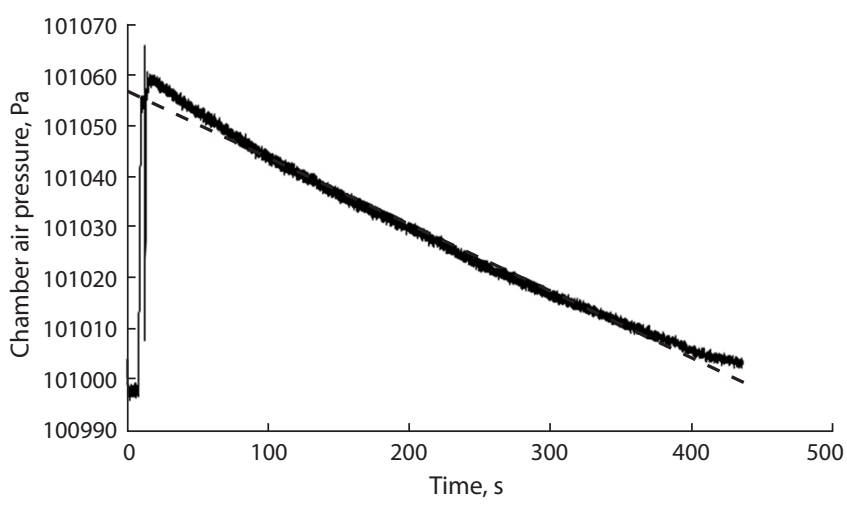

Fig. 1. Example of oxygen consumption measurement.

The solid line is the pressure in the chamber; the dotted line is the approximating line.

graph was measured (Fig. 1). For the purposes of statistical analysis, the average value for two repeated measurements was considered. The flies were weighed immediately after the experiment. Four experiments were carried out in total.

The locomotor activity in the male flies of the tested strains was monitored using TriKinetics Drosophila Activity Monitor ("Trikinetics", Waltham, MA, United States). To perform the monitoring, each male was placed in a glass tube containing its standard feed. The locomotor activity of the fly was determined as the number of times the fly crossed an infrared beam per minute within five days. For each fly, its daily average locomotor activity was calculated based on its average hourly activity from 11 a.m. to 4 p.m. from day 2 to day 4 of the experiment. The flies that did not survive until the end of the experiment were excluded from the analysis. For each strain, 12 to 16 flies (3-7 days) were analyzed. The experiment was conducted at $29^{\circ} \mathrm{C}$.

The life span of the tested flies was determined at the same temperature $\left(29^{\circ} \mathrm{C}\right)$, each tube containing 20 male flies. For each strain, five tubes were analyzed.

Statistical analysis. The results were evaluated with Statistica 6.0. To compare the mean values, Fisher's least significant difference method (LSD) was applied. The life span was estimated by the logrank test (Bland, Altman, 2004) with the $\chi^{2}$ statistics.

\section{Results}

In daytime hours, the maximum locomotor activity was recorded in $\mathrm{M}$ (III) - mitotype flies (Fig. 2). Their average daily activity was $51.2 \pm 5.9$ crossings per hour, which was statistically higher $(p<0.02)$ than in $\mathrm{S}(\mathrm{VI})(39.9 \pm 2.9)$ or $\mathrm{M}(\mathrm{V})(35.0 \pm 4.0, p<0.05)$. The difference between the $\mathrm{M}(\mathrm{V})$ and $\mathrm{S}(\mathrm{VI})$ mitotypes in average daily activity was insignificant $(p>0.4)$.

The average oxygen consumption per fly was $2.76 \mu \mathrm{l} / \mathrm{h}$. In the studied flies, this parameter statistically correlated with body weight $(\mathrm{R}=0.44, p \approx 0.01$ ) (Fig. 3 ). When averaged over strain, the values of oxygen consumption correlated with the average daily activity $(\mathrm{R}=0.61, p \approx 0.1)$. However, when calculated as oxygen consumption per mg of fly body weight, they statistically correlated with neither body weight $(p>0.2)$ nor average daily activity $(p>0.8)$. The performed experiments demonstrated statistically significant differences

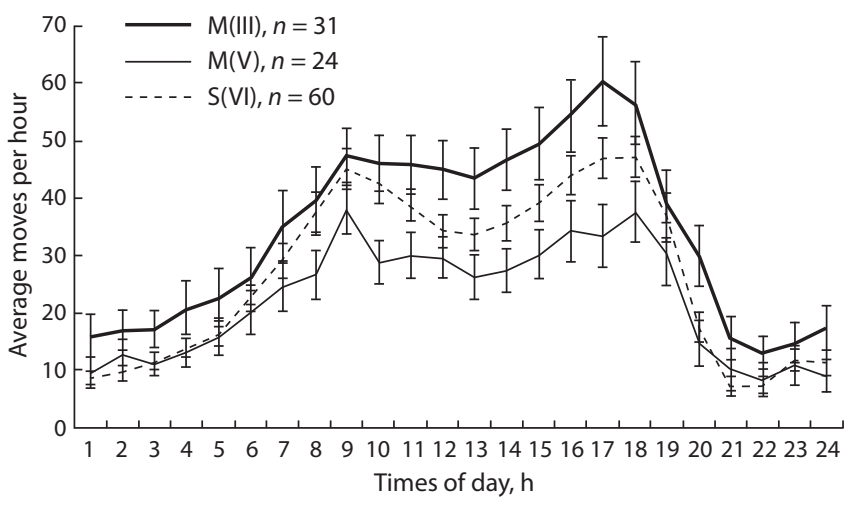

Fig. 2. The daily dynamics of the locomotor activity in different Drosophila mitotypes (mean $\pm \mathrm{SE}$ ).

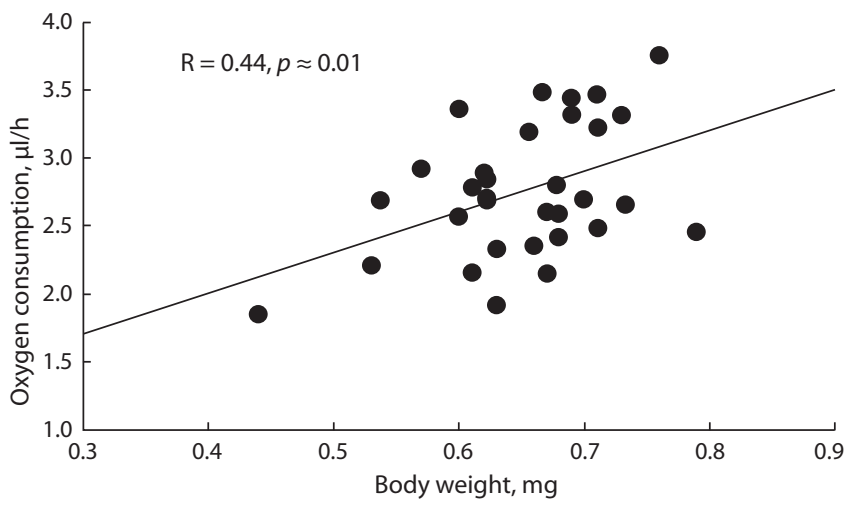

Fig. 3. Correlation of the average values of oxygen consumption with the average body weight of flies.

Energy expenditure in different Drosophila mitotypes

\begin{tabular}{|c|c|c|c|c|}
\hline \multirow[t]{2}{*}{ Mitotype } & \multirow[t]{2}{*}{$n$} & \multirow{2}{*}{$\begin{array}{l}\text { Body weight, } \\
\text { mg }\end{array}$} & \multicolumn{2}{|c|}{ Average oxygen consumption } \\
\hline & & & $\begin{array}{l}\text { per fly, } \\
\mu l / h\end{array}$ & $\begin{array}{l}\text { per gram body } \\
\text { weight, } \\
\mathrm{ml} / \mathrm{g} / \mathrm{h}\end{array}$ \\
\hline$M(I I I)$ & 8 & $0.662 \pm 0.014$ & $2.83 \pm 0.19$ & $4.27 \pm 0.25$ \\
\hline $\mathrm{M}(\mathrm{V})$ & 8 & $0.653 \pm 0.019$ & $2.79 \pm 0.19$ & $4.31 \pm 0.35$ \\
\hline $\mathrm{S}(\mathrm{VI})$ & 12 & $0.644 \pm 0.023$ & $2.70 \pm 0.11$ & $4.21 \pm 0.12$ \\
\hline
\end{tabular}

Notes: $n$-number of flies; the data are presented as mean \pm SE.

between the mitotypes in neither body weight nor oxygen consumption (Table).

The life span in the M(III) mitotype flies was statistically higher than that in the S(VI) $\left(\chi^{2}=9.24, p<0.01\right)$ and $\mathrm{M}(\mathrm{V})$ $\left(\chi^{2}=4.83, p<0.05\right)$ mitotypes. No statistically significant differences between the $\mathrm{S}(\mathrm{VI})$ and $\mathrm{M}(\mathrm{V})$ mitotypes were found (Fig. 4).

\section{Discussion}

The studied M(III) - mitotype flies demonstrated the higher level of locomotor activity, but their energy expenditure was close to that in flies of $\mathrm{M}(\mathrm{V})$ and $\mathrm{S}(\mathrm{VI})$ mitotypes, which can be considered an adaptive advantage of M(III) flies. The 


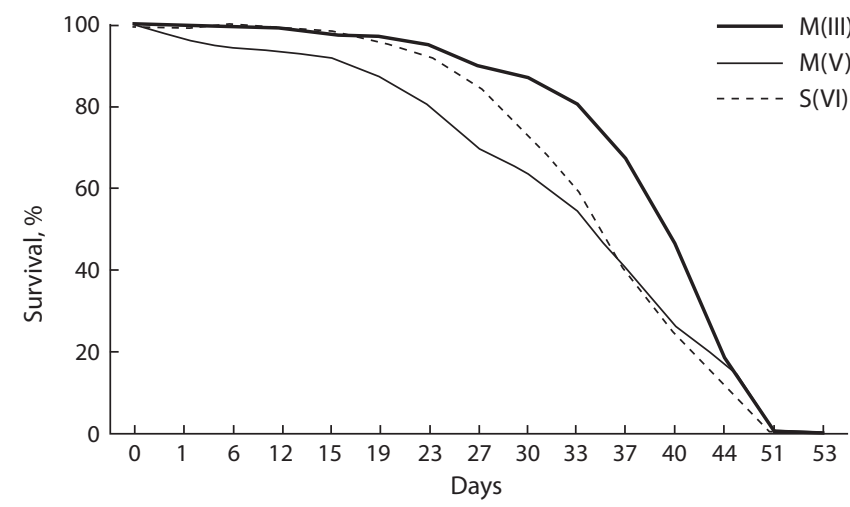

Fig. 4. Life spans of males with different mitotypes.

dependence of oxygen consumption on locomotor activity can be linearly approximated (Schmidt-Nielsen, 1982), so the inclination angle of the line can be interpreted as price of activity or efficiency, while its vertical intercept reflects the metabolic rate at rest (metabolic rate at zero activity). This is important, because the same level of energy expenditure in flies with different genotypes can be distributed differently between the rest and active states.

Since in our study we had only one activity/energy expenditure point on the plane for each mitotype, and since through a single point a myriad of lines can be drawn, we could not unambiguously estimate the energy distribution between the rest and active states. Nevertheless, we can consider two extreme cases.

If in flies with different mitotypes the energy expenditure values at rest are similar, the approximating lines for these mitotypes would have different inclination angles, hence different prices of activity (Fig. 5, a). The least steep line (for M(III) mitotype) means that these individuals can move further distance or remain active longer spending the same amount of energy, which can be interpreted as an advantage of the mitotype if compared to the others. However, if individuals have different energy expenditures at rest (See Fig. $5, b$ ) and similar prices of activity (similar approximation curve inclination angles), then the M(III) strain would get an advantage over the strains of the other studied mitotypes, because the least energy expenditures at rest would help these flies spend less energy during inevitable inactivity under unfavorable conditions.

From all viewpoints, the actual pattern seems to be a combination of the two extreme cases, and in order to study the way energy expenditure depends on the activity parameter it is strongly recommended to investigate both parameters simultaneously. In this case, a series of energy expenditure and activity values can be obtained for every strain, which makes it possible to trace the true effect of a mitotype.

In $D$. simulans, the life span does not correlate with exhaled $\mathrm{CO}_{2}$ (Melvin et al., 2007). The same was confirmed in our experiments with $D$. melanogaster. However, the life span of the M(III) mitotype male flies kept under extreme conditions $\left(29^{\circ} \mathrm{C}\right)$ turned out to be higher than those of the $\mathrm{M}(\mathrm{V})$ and $\mathrm{S}(\mathrm{VI})$ mitotypes, whose life expectancies were similar.

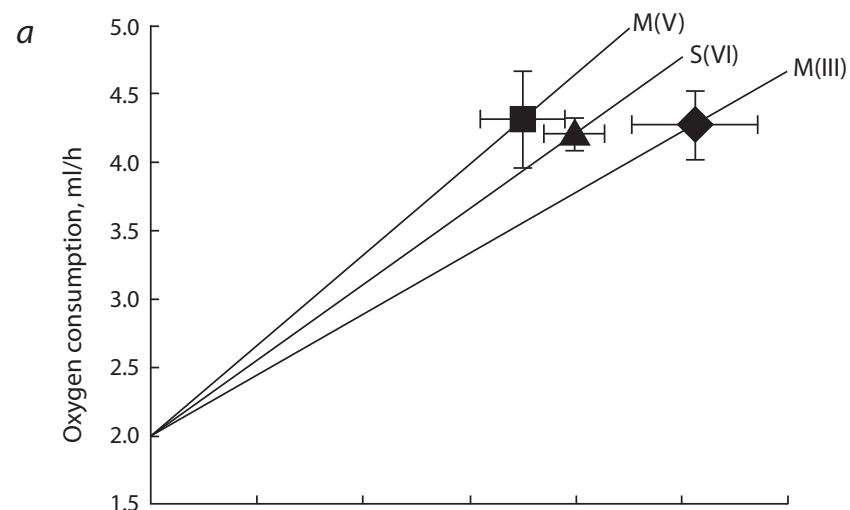

$b$

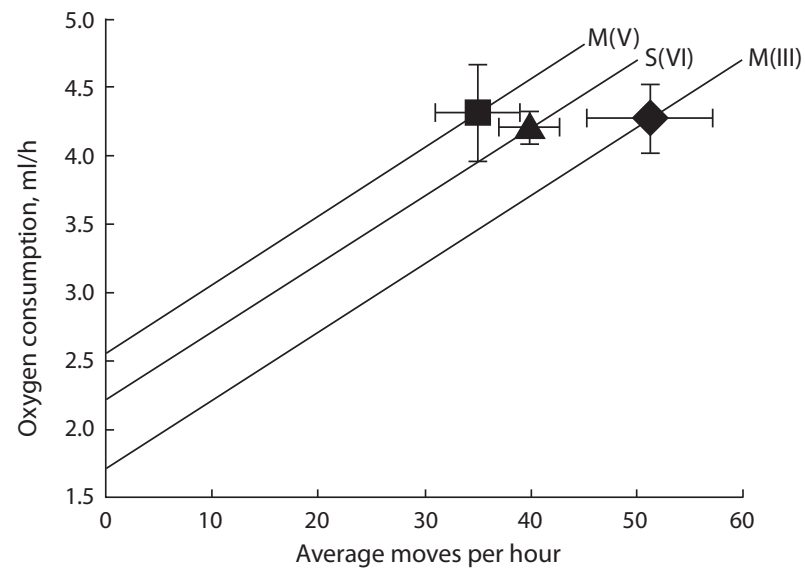

Fig. 5. Hypothetical variants of energy expenditure dependence on the locomotor activity in flies with different mitotypes.

$a$, flies with different mitotypes have the same level of oxygen consumption at zero activity, but the angles of inclination of the approximating straight lines are different; $b$, flies with different mitotypes have the same angles of inclination of the approximating straight lines, but the levels of oxygen consumption differ at zero activity. The lower straight line is $\mathrm{M}(\mathrm{III})$, the upper is $M(V)$, and the middle is $S(V I)$.

\section{Conclusion}

We assume that individuals of the M(III) mitotype strain, belonging to the most widespread clade, have adaptive advantages as compared to the other mitotypes due to their higher locomotor activity. Which nucleotide substitutions in M(III) are responsible for this advantage remains an open issue, and further investigation should be performed with more strains related to the same clade and to other mitotic clades.

\section{References}

Bland J.M., Altman D.G. The logrank test. The BMJ. 2004;328:10731074.

Clancy D.J. Variation in mitochondrial genotype has substantial lifespan effects which may be modulated by nuclear background. Aging Cell. 2008;7(6):795-804. DOI 10.1111/j.1474-9726.2008. 00428.x.

Diarra G.M., Roberts T.W., Christensen B.M. Automated measurement of oxygen consumption by the yellow fever mosquito, Aedes aegypti. Am. J. Trop. Med. Hyg. 1999;60:859-864.

Early A.M., Clark A.G. Monophyly of Wolbachia pipientis genomes within Drosophila melanogaster: geographic structuring, titre variation and host effects across five populations. Mol. Ecol. 2013;23: 5765-5778. DOI 10.1111/mec.12530.

Gruntenko N.E., Ilinsky Y.Y., Adonyeva N.V., Burdina E.V., Bykov R.A., Menshanov P.N., Rauschenbach I.Y. Various Wolbachia 
genotypes differently influence host Drosophila dopamine metabolism and survival under heat stress conditions. BMC Evol. Biol. 2017;17(Suppl. 2):252. DOI 10.1186/s12862-017-1104-y.

Halliwell B. Free radicals and antioxidants: updating a personal view. Nutr. Rev. 2012;70:257-265. DOI 10.1111/j.1753-4887.2012. 00476.x.

Harman D. Aging: a theory based on free radical and radiation chemistry. J. Gerontol. 1956;11:298-300. DOI 10.1093/geronj/11.3.298.

Ilinsky Y. Coevolution of Drosophila melanogaster mtDNA and Wolbachia genotypes. PLoS One. 2013;8(1):e54373. DOI 10.1371/ journal.pone.0054373.

Ilinsky Yu.Yu., Bykov R.A., Zakharov I.K. Cytotypes of mutant Drosophila melanogaster stocks from the collection of the genetics of population laboratory of the Institute of Cytology and Genetics SB RAS: genotypes of the Wolbachia endosymbiont and host mitotypes. Vavilovskii Zhurnal Genetiki i Selektsii = Vavilov Journal of Genetics and Breeding. 2013;17:407-415. (in Russian)

Katewa S.D., Ballard J.W. Sympatric Drosophila simulans flies with distinct mtDNA show difference in mitochondrial respiration and electron transport. Insect Biochem. Mol. Biol. 2007;37(3):213-222.

Lehmann G., Segal E., Muradian K.K., Fraifeld V.E. Do mitochondrial DNA and metabolic rate complement each other in determination of the mammalian maximum longevity? Rejuvenation Res. 2008; $11: 409-417$

Maklakov A.A., Friberg U., Dowling D.K., Arnqvist G. Within-population variation in cytoplasmic genes affects female life span and aging in Drosophila melanogaster. Evolution. 2006;60:2081-2086.
Melvin R.G., Van Voorhies W.A., Ballard J.W. Working harder to stay alive: metabolic rate increases with age in Drosophila simulans but does not correlate with life span. J. Insect Physiol. 2007;53: 1300-1306.

Min K.T., Benzer S. Wolbachia, normally a symbiont of Drosophila, can be virulent, causing degeneration and early death. Proc. Natl. Acad. Sci. USA. 1997;94:10792-10796.

Muradian K.K., Lehmann G., Fraifeld V.E. NUMT ("new mighty") hypothesis of longevity. Rejuvenation Res. 2010;13:152-155. DOI 10.1089/rej.2009.0974.

Richardson M.F., Weinert L.A., Welch J.J., Linheiro R.S., Magwire M.M., Jiggins F.M., Bergman C.M. Population genomics of the Wolbachia endosymbiont in Drosophila melanogaster. PLoS Genet. 2012;8(12):e1003129. DOI 10.1371/journal.pgen.1003129.

Rottenberg H. Coevolution of exceptional longevity, exceptionally high metabolic rates, and mitochondrial DNA-coded proteins in mammals. Exp. Gerontol. 2007;42(4):364-373.

Schmidt-Nielsen K. Animal Physiology: Adaptation and Environment. London-New York, Cambridge University Press, 1975. (Russ. ed. Schmidt-Nielsen K. Animal Physiology: Adaptation and Environment. Book 1. Moscow: Mir Publ., 1982). (in Russian)

Stuart J.A., Brown M.F. Mitochondrial DNA maintenance and bioenergetics. Biochim. Biophys. Acta. 2006;1757(2):79-89.

Zhu C.T., Ingelmo P., Rand D.M. $\mathrm{G} \times \mathrm{G} \times \mathrm{E}$ for lifespan in Drosophila: mitochondrial, nuclear, and dietary interactions that modify longevity. PLoS Genet. 2014;10(5):e1004354. DOI 10.1371/journal. pgen. 1004354.

\section{ORCID ID}

D.V. Petrovskii orcid.org/0000-0002-0623-0363

L.P. Zakharenko orcid.org/0000-0002-6341-8522

Acknowledgements. The study was supported by State Budgeted Project 0324-2019-0041. Use of the equipment provided by the Shared Access"Center of Laboratory Animal Genetic Resources" of the Institute of Cytology and Genetics (Novosibirsk), was supported by the Russian Ministry of Education and Science (unique project identifier RFMEFI62117X0015).

The authors are grateful to N.E. Gruntenko for providing the specimen strains, and to Yu.Yu. Ilinsky for information on mitotype characteristics.

Conflict of interest. The authors declare no conflict of interest.

Received October 23, 2018. Revised January 18, 2019. Accepted February 1, 2019. 